Original article (short paper)

\title{
Postural control during one-leg stance in active and sedentary older people
}

\author{
Leonardo George Victorio Victor \\ Márcio Rogério de Oliveira \\ Denilson de Castro Teixeira \\ Maria Amélia Paes \\ University of North of Paraná, Londrina, Brazil \\ Dirce Shizuko Fujisawa \\ State University of Londrina, Brazil \\ Nuno de Noronha da Costa Bispo \\ Rubens Alexandre da Silva Junior \\ University of North of Paraná, Londrina, Brazil
}

\begin{abstract}
Physical inactivity and aging are functional disability factors for older individuals, causing loss of balance and increasing the risk of falls. The purpose of this study was to compare the balance of physically independent older individuals, both participants and non-participants in a regular exercise program. Fifty six physically independent older participants were divided into $\mathrm{G} 1_{\text {ACTIVE }}=28$ individuals who participate in a regular exercise program and $\mathrm{G} 2_{\text {SEDENTARY }}$ $=28$ individuals who did not participate in any physical exercise program. All participants underwent an eyes-open during one-leg balance test on a force platform. The postural oscillation parameters included center of pressure (COP); sway mean velocity and frequency of COP oscillations. G2 ${ }_{\text {SEDENTARY }}$ showed higher postural instability than $\mathrm{G}_{\text {ACTIVE }}$. Significant differences were observed for the main balance parameters. The results of this study support the concept that participation in regular physical activity is beneficial for postural balance of older individuals.
\end{abstract}

Keywords: postural balance, aging, movement, exercise

Resumo - "Controle postural durante suporte unipodal em idosos ativos e sedentários." A inatividade física e o envelhecimento são fatores de incapacidade funcional em idosos, causando perda de equilíbrio e aumentando o risco de quedas. Esta pesquisa comparou o equilíbrio postural de idosos fisicamente independentes, participantes e não participantes de um programa de exercício físico regular. Cinquenta e seis idosos fisicamente independentes foram divididos em $\mathrm{G} 1_{\text {Ativo }}(n=$ 28) participante de um programa de exercício físico regular, e $\mathrm{G}_{\text {Sedentário }}(n=28)$ não inserido em programas de exercício físico. Todos os idosos foram avaliados durante a tarefa de equilíbrio, em apoio unipodal sobre uma plataforma de força, mediante os parâmetros de oscilação posturais centro de pressão (COP), oscilação da velocidade média e frequência de oscilação do COP. O G2 mostrou maior instabilidade postural que o G1. Foram observadas diferenças significativas para os principais parâmetros de equilíbrio. Os resultados levam a conclusão de que um programa de atividade física regular é benéfico para o equilíbrio postural de idosos.

Palavras-chave: equilíbrio postural, envelhecimento, movimento, exercício

Resumen - "El control postural durante la pata de apoyo único en activo y sedentario ancianos." La inactividad física y el envejecimiento son factores de discapacidad en los ancianos, causando la pérdida de equilibrio y aumentar el riesgo de caídas. Esta investigación comparó el equilibrio postural en personas mayores físicamente independientes, que participan y que no participan en un programa de ejercicio regular. Cincuenta y seis ancianos físicamente independientes fueron divididos en $\mathrm{G}_{\text {activo }}(n=28)$ que participo en un programa de ejercicio regular, y $2_{\text {sedentario }}(n=28)$ no incluido en los programas de ejercicio físico. Todos ellos fueron evaluados para la tarea de mantener el equilibrio sobre un pie, sobre una plataforma de fuerza, utilizando los parámetros del centro de balanceo postural de la presión (COP), la velocidad media y la frecuencia de oscilación. G2 mostró una mayor inestabilidad postural que el G1. No se observaron diferencias significativas en los principales parámetros de equilibrio. Los resultados llevan a la conclusión de que un programa de actividad física regular es beneficioso para el equilibrio postural en los ancianos.

Palabras clave: equilibrio postural, envejecimiento, movimiento, ejercicio 


\section{Introduction}

Due to the aging process, the neuromuscular system undergoes physiological and morphological alterations (Jiang, Cooper, Porter, \& Ready, 2004) that lead to decreased muscle performance and functional capacity. Combined with a sedentary lifestyle, these alterations reduce the functional reserve capacity of older individuals, making them physically weaker, slower and with reduced motor coordination when compared to young adults (Enoka, 1994). Postural control also deteriorates during the aging process. Intrinsic factors related to neuromuscular control, as well as extrinsic factors such as the environment may result in loss of balance and, consequently, in falls. Some studies suggest that postural instability is one of the most common causes of falls among older individuals (Viswanathan \& Sudarsky, 2012). Falls currently represent one of the largest public health problems (Hsiao \& Simeonov, 2001; Lord, Sherrington, \& Menz, 2001) and are the main causes of death among older individuals (Morley, 2007).

The maintenance of active lifestyle is recommended as an important strategy for preserving the physical aptitude of older individuals since it preserves functional capacities and reduces falls (Armstrong, Bates, Castell, \& Krolik, 2002). In a pilot randomized clinical trial by Clemson et al. (2010) with a participants over 70 years old, a six-month exercise program included a set of muscle strength exercises for the lower limbs and for balance. After participation in the program, individuals showed better dynamic balance and reduction of fall rates compared to those who did not participate in the exercise program. Another study with older individuals demonstrated that there was an improvement in the one-leg stance time of those who participated in 20 sessions of balance and muscle strength exercises compared to those who did not. The authors also observed that, after six months, those who did not participate in the program presented higher rate of falls (Domínguez-Carrillo, Arellano-Aguilar, \& Leos-Zierold, 2007). However, one-leg stance time represents one functional domain of measurements designed to assess physical capacity such as endurance and strength.

Balance can be quantified using direct measurements of posture control such as center of pressure (COP) parameters recorded when using a force platform during one-leg stance (Da Silva et al., 2013). This method has been valid and reliable for measuring balance COP parameters associated to biomechanical and neuromuscular mechanisms of both young and older individuals (Da Silva et al., 2013).

Results in the literature often report data from standing task conditions. However, it would be interesting to generalize some results to more challenging tasks required in daily motor activities (e.g., turning, climbing stairs, walking, dressing) when succession of two-to-one-leg standing occurs. A more challenging standing condition could predict incidence of falls, and better determine potential effects of physical exercise interventions on balance.

Based on these considerations, the main purpose of this study was to compare, using COP force platform parameters, how static balance during a one-leg stance of physically independent older individuals is affected by participation in regular physical exercise programs. Our hypothesis is that older participants who participate in regular physical activities show better postural control than non participants.

\section{Methods}

The study used a cross-sectional design. The sample consisted of 56 physically independent older individuals of both sexes (26 women), who were divided into two groups: an active group $\left(\mathrm{G} 1_{\text {ACTIVE }}\right)$ of 28 older individuals who participated in a physical exercise program, and a sedentary group ( $\left.\mathrm{G} 2_{\text {SEDENTARY }}\right)$ of 28 older individuals from the community who did not participate in the physical exercise program or had any regular supervised physical activity. The $\mathrm{G} 2$ SEDENTARY was randomly selected from the PSF (Programa Saúde da Família - Family Health Program) files from health centers of the five regions of the city of Londrina, State of Paraná, Brazil.

The inclusion criteria were that all participants should be physically independence and over 60 years old. The exclusion criteria were: 1) presence of any mental or physical disorders that could interfere in the tests; 2) surgical procedures after locomotion impairments or injuries; 3 ) presence of severe musculoskeletal disorders with use of drugs and 4) fall in the last year. All participants signed an informed consent form. The study was approved by the Research Ethics Committee of the local University (no. PP/0070/09).

Only one laboratory session was necessary to carry out the experimental evaluations. Initially, all participants were familiarized with the task protocol and the equipment. The balance tests were carried out in the Laboratory of Functional Evaluation and Human Motor Derformance (LAFUP). Noise was kept to a minimum, and testing was conducted by trained evaluators. Participants' body mass and height were measured and body mass index was calculated according to recommendations by Gordon, Chumlea, and Roche (1988). The Baecke Physical Activity Questionnaire adapted for older individuals (QBMI) (Mazo, Mota, Benedetti, \& Barros, 2001; Voorrips et al., 1991) was also used to classify the participants as either active $\left(\mathrm{Gl}_{\text {ACTIVE }}\right)$ or sedentary $\left(\mathrm{G} 2_{\text {SEDENTARY }}\right)$. Significant differences $(p<.05)$ between-groups were reported for this variable to confirm the active physical level of each group (Table 1). Self-reports about active lifestyle was also registered in the ACSM. Active participants were recruited from the PROVIDA supervised exercise program at the University of North of Paraná (UNOPAR). They were enrolled in the program for at least two years. The physical exercise program routine included two 60-min sessions each week; each session was divided in 15 minutes neuromotor exercises (e.g., balance, body agility and motor coordination), 25 minutes muscle strength and 20 minutes flexibility exercises (Figure 1). The exercises were of mild to moderate intensity, and instructors used alternative material resources, such as pieces of elastic, batons, ankle weights, and 1-2 kg dumbbells. The neuromotor exercises instructions were presented in a playful manner, although instructors challenged participants to perform as many repetitions as possible in each task. Strength exercises 
included three sets of 15 reps each exercise, involving lower and upper trunk muscles and abdomen. Intensity of exercises was not controlled due to technical limitations of the fitness equipment. In the exercise of muscle resistance, loads were determined with basis on the current physical condition of each participant; beginners started without load but, after adaptation to exercise, they added a $0.5-1 \mathrm{~kg}$ load. Flexibility exercises were targeted to muscle groups used in the strength exercises. These were performed in two repetitions each, for 30 seconds, using the active static method.

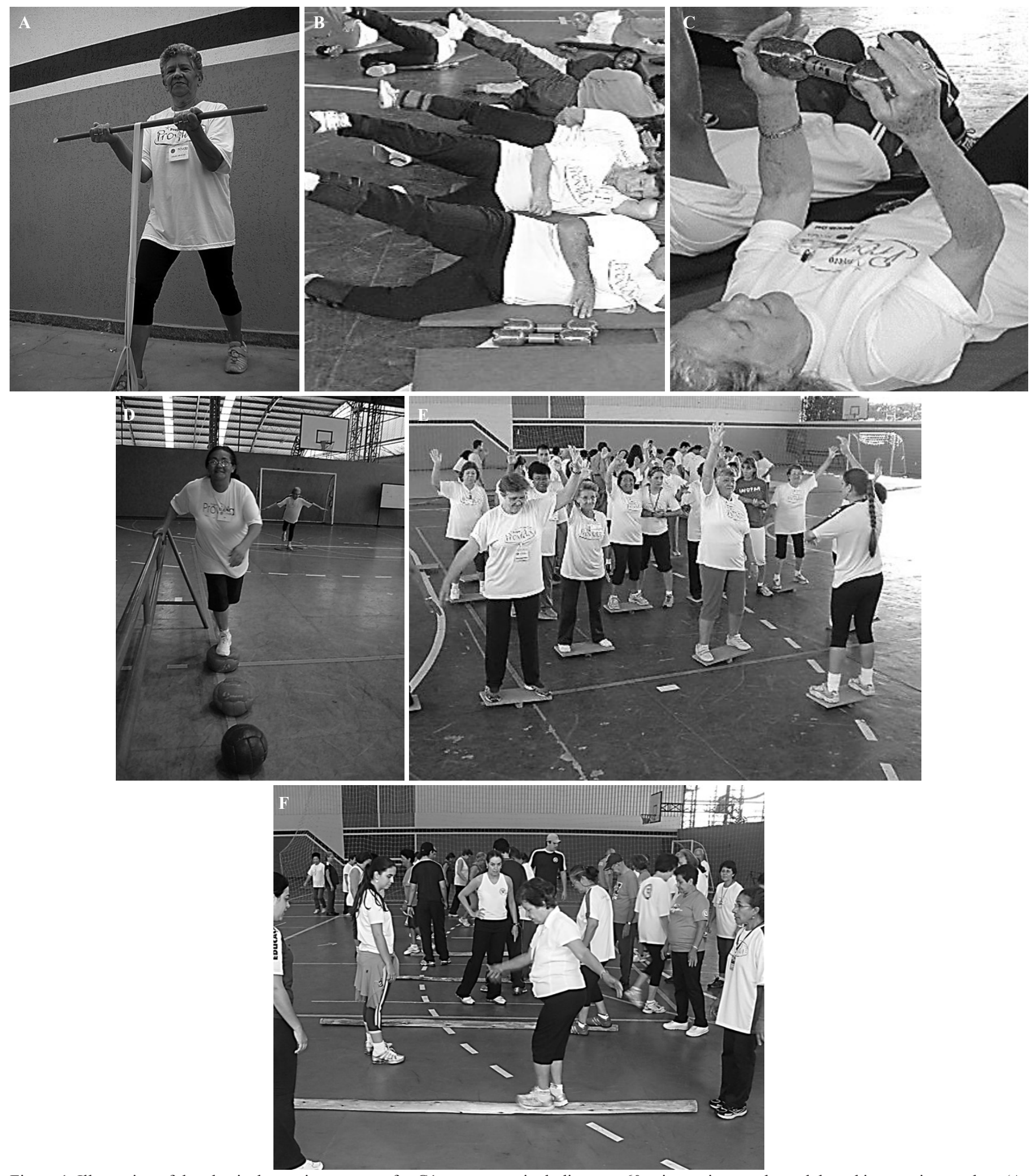

Figure 1. Illustration of the physical exercise program for $\mathrm{G}_{\text {ACTIVE }}$ group including two 60 -min sessions each week based in exercises such as (A, D) flexibility, (B, C, E) strength of lower-limb, and (F) postural balance. 
In the laboratory, both groups $\left(\mathrm{G} 1_{\mathrm{ACTIVE}}\right.$ and $\left.\mathrm{G} 2_{\text {SEDENTARY }}\right)$ performed the one-leg stance balance test on a force platform (BIOMEC400, EMG System do Brasil, SP, Ltda) using their preferred leg (Da Silva et al., 2013; Gil et al., 2011; Parreira et al., 2013). A standardized protocol was used for the test. During all trials, participants were instructed to stand in one leg (see fig.2 for illustration), eyes open and gazing a target (black cross $14.5 \mathrm{x}$ $14.5 \times 4 \mathrm{~cm}$ ) placed on a wall at eye level $2 \mathrm{~m}$ away, while keeping their arms at their sides or parallel to their trunk. Three trials (30 $\mathrm{s}$ maximum) were performed with a $30 \mathrm{~s}$ rest interval between each of them. The mean value of the three trials was later used for analysis (Da Silva et al., 2013; Gil et al., 2011; Parreira et al., 2013). Two evaluators remained close to the participants (behind and beside the individual) during all the time to prevent falls and to ensure the safety of the experiment (Figure 2).

The BIOMEC400 platform's Bioanalysis software was used to obtain and analyze the balance parameters, which were compiled using MATLAB analysis routines (Mathworks, Natick, MA) (Da Silva et al., 2013; Gil et al., 2011; Parreira et $a l ., 2013)$. The vertical force of the ground reaction is derived from a sample of $100 \mathrm{~Hz}$ data collection. All force signals recorded by the platform were filtered with a $35 \mathrm{~Hz}$ second-order low band pass filter (Butterworth filter) to eliminate electronic noise. The main balance parameters based on the COP were computed (the higher the values, the worse the balance): Ellipse area $(95 \%)$ of the COP (A-COP in $\left.\mathrm{cm}^{2}\right)$, mean velocity (VEL in $\mathrm{cm} / \mathrm{s}$ ) and mean frequency (MF in $\mathrm{Hz}$ ) of COP oscillations in both directions of movement: Anterior-Posterior $(\mathrm{A} / \mathrm{P})$ and Mediolateral (M/L). These balance parameters were calculated from of $4.99 \mathrm{~s}$ to the total duration (maximum $30 \mathrm{~s}$ ) of the trial

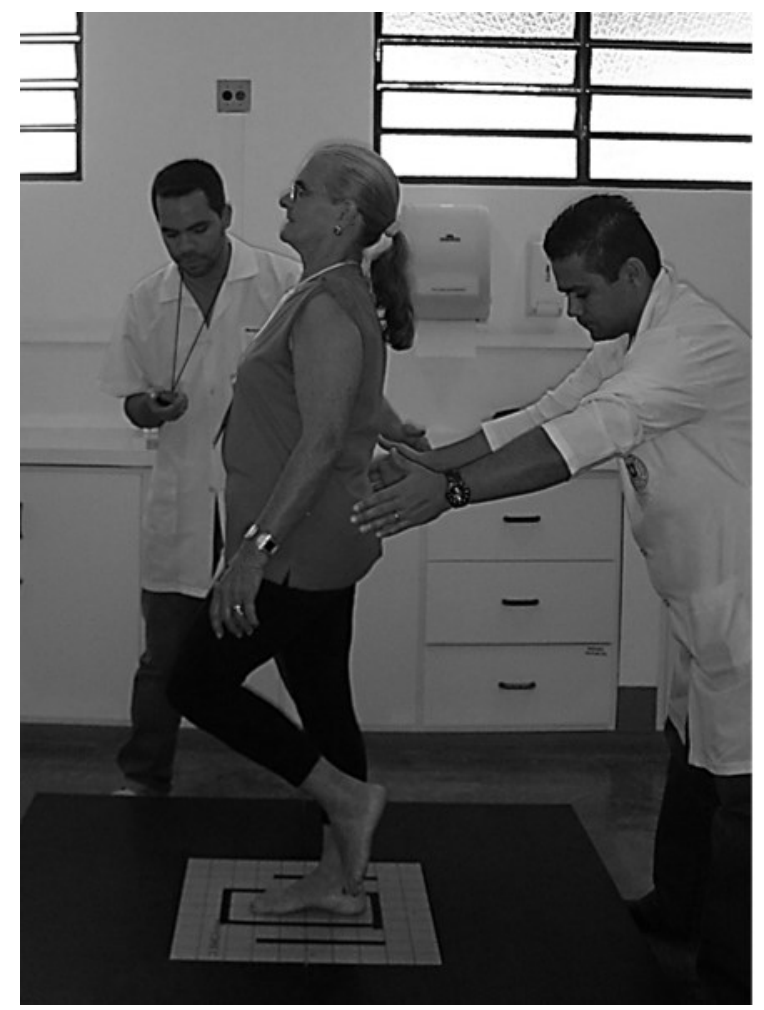

Figure 2. Evaluation of one-leg stance on the force platform (BIOMEC 400). for each subject (Parreira et al., 2013). All these balance parameters were validated and reliability tests established for both older and young individuals (Da Silva et al., 2013).

The data were analyzed using descriptive statistics, with mean and standard deviation (SD). Normal data distribution was verified with the Shapiro-Wilk test. Student's $t$-tests were used for between-group $\left(\mathrm{G} 1_{\text {ACTIVE }}\right.$ and $\left.\mathrm{G} 2_{\text {SEDENTARY }}\right)$ comparisons for all variables (anthropometric and balance). All statistical analyses were performed with SPSS statistical software (version 15.0 for Windows) with an alpha level of $p<.05$.

\section{Results}

The two groups were homogenous in their anthropometric characteristics such as: age, mass, height, BMI (Table 1). The active group's mean of physical activity level was $9.95( \pm 8.73)$ points, whereas the sedentary group's was $4.76( \pm 3.26)$. The significant differences $(p<.01)$ between both groups ensured the physical activity level criteria for group assignment $\left(\mathrm{G} 1_{\text {ACTIVE }}\right.$ and $\mathrm{G} 2_{\text {SEDENTARY }}$ ).

The COP postural balance parameters (A-COP, VEL for both directions) showed significant differences $(p<.05)$ between the two groups (Table 2). Mean values of COP parameters indicated better performance by the active group compared to the sedentary group, with exception of MF balance parameter in $\mathrm{M} / \mathrm{L}$ direction.

Table 1. Anthropometric and physical activity characteristics of the participants.

\begin{tabular}{lccccc}
\hline Variables & $\begin{array}{c}\text { G1 Active } \\
\text { Mean (SD) }\end{array}$ & $\begin{array}{c}\text { G2 } \\
\text { MeanentaRY }\end{array}$ & $t$ & $d f$ & $p$ \\
\hline Age (years) & $67(5)$ & $69(7)$ & -0.23 & 54 & .820 \\
Mass (Kg) & $69(10)$ & $70(14)$ & -2.05 & 54 & .060 \\
Height (m) & $1.57(0.8)$ & $1.61(0.11)$ & 0.98 & 54 & .334 \\
BMI ( kg/m $)$ & $27(3)$ & $26(4)$ & -1.56 & 54 & .132 \\
Phys. act. level & $9.95(8.73)$ & $4.76(3.26)$ & 5.34 & 54 & $<.01^{*}$ \\
\hline
\end{tabular}

The data are the mean with the standard deviation in parenthesis. ${ }^{*} p<.01$ : signifi

BMI: body mass index.

Physical activity level was evaluated with the Baecke questionnaire.

Table 2. Comparison of balance between groups from platform measurements.

\begin{tabular}{lccccc}
\hline Variables & $\begin{array}{c}\text { G1 } \\
\text { Mean (SD })\end{array}$ & $\begin{array}{c}\text { G2 } \\
\text { Mean (SD) }\end{array}$ & & $d f$ & $p$ \\
\hline Area-COP $\left(\mathrm{cm}^{2}\right)$ & 10.02 & 19.33 & -2.36 & 54 & $.023^{*}$ \\
& $(3.30)$ & $(7.21)$ & & & \\
VEL-AP (cm/s) & $3.09(1.44)$ & $5.82(3.11)$ & -3.85 & 54 & $<.01^{*}$ \\
VEL - ML (cm/s) & $4.02(1.16)$ & $5.60(1.71)$ & -0.56 & 54 & $.01^{*}$ \\
MF - AP (Hz) & $0.73(0.28)$ & $0.96(0.28)$ & -2.82 & 54 & .07 \\
MF- ML (Hz) & $0.90(0.22)$ & $0.91(0.35)$ & -0.03 & 54 & .97 \\
\hline
\end{tabular}

The data are the mean with the standard deviation in parenthesis. ${ }^{*} p<.05$ : significant differences between groups (G1- ${ }_{\text {ACTIVE }}$ vs G2- ${ }_{\text {SEDENTARY }}$ ). COP: Center of pressure VEL: Velocity of COP oscillation MF: Mean Frequency COP oscillation in both directions, Anterior-Posterior (A/P) and Mediolateral (M/L). 


\section{Discussion}

Although we did not evaluate the effects of the program using a longitudinal design, our results support that regular physical activity (twice a week) is efficient for maintaining the status of balance in older individuals. In summary, the G1 $1_{\text {ACTIVE }}$ presented higher levels of postural stability when performing one leg-stance than did the $\mathrm{G} 2{ }_{\text {SEDENTARY }}$. The fitness level of participants was confirmed by homogeneity of sample in anthropometric measures and physical activity levels (Table 1). Such finding reduces influence of confounding effects on COP measurements.

Different from studies that evaluate balance in older individuals using a force platform (Corriveau, Hebert, Prince, \& Raiche, 2000; Lafond, Corriveau, Hebert, \& Prince, 2004; Lin, Seol, Nussbaum, \& Madigan, 2008), our study introduces a more challenging situation for the postural control system, and its one-foot stance can be observed in functional activities such as climbing stairs (Clifford, \& Holder-Powell, 2010) . Even though the present study did not evaluate the effects of the physical activity program in a randomized clinical trial design, our results corroborate others studies (Alfieri et al., 2010; Orr, Raymond, \& Fiatarone; Steadman, Donaldson, \& Kalra, 2003). In a literature review, Howe et al. (2007) concluded that physical exercise improves postural balance in older individuals. In addition, Orr (2010) demonstrated that $54 \%$ of the clinical trials based on muscle strength training effectively improved postural balance among older individuals.

Matsudo et al. (Matsudo, Matsudo, \& Barros Netto, 2001) also advocates the importance of regular physical activity programs that include lower-limb muscle strength training, flexibility and balance training for improving quality of life and reducing the neuromuscular deficits associated with aging. According to the American College of Sports Medicine (ACSM), physical exercise has beneficial effects on the neuromuscular system, such as muscle mass gains, prevention of muscle strain, improvement of neuromuscular control and balance, and maintenance of functional capacities for the activities of daily living (Nelson et al., 2007).

Due to the aging process, the musculoskeletal system undergoes certain changes such as loss of neuromuscular, muscle strength and functional capacity (Jiang, Cooper, Porter, \& Ready, 2004; Lord, Sherrington, \& Menz, 2001). Therefore, such changes associated with physical inactivity may lead to fast deterioration of older individuals' functional capacities (Matsudo, Matsudo, \& Barros Netto, 2001). Individuals who are physically active have fewer physical limitations that impact the quality of their lives (Franchi \& Montenegro, 2005).

Postural control enables appropriate contractions of the muscle groups responsible for the maintenance of balance (Ekwall, Lindberg, \& Magnusson, 2009; Franchi \& Montenegro, 2005). Participation in physical activity programs is essential for mitigating the natural deficits of aging (Kuhnen et al., 2004). Also, it is essential to help maintain muscular strength, endurance, and sensory motor responses in older individuals. In fact, individuals who are not engaged in physical activity program can present poor postural balance, as we found for the $\mathrm{G} 22_{\text {SEDENTARY }}$ in the present study. Subsequently, poor physical qualities increase the risk for falls (Marques et al., 2011).

Postural instability is one of the most common causes for falls among older individuals (Hsiao \& Simeonov, 2001; Viswanathan \& Sudarsky, 2012). Falls represent one of the largest public health problems (Hsiao \& Simeonov, 2001; Viswanathan \& Sudarsky, 2012), and is the main cause of mortality among older individuals. Therefore, there is an increased awareness among public policymakers about the need to develop intervention and prevention methods that encourage older individuals to participate in regular physical activity.

Finally, some limitations of this study must be mentioned. Although the positive results of active participants in balance skills may be related to their long term participation in the physical activity program, a cross-sectional design would reinforce our claims about effects of physical activity intervention on balance.

In conclusion, older individuals who participated in a physical exercise program presented better balance performance than those who did not participate. Physical exercise contributed to better performance by these individuals in a one single-leg stance test. Given that postural instability is an important risk for falls and subsequent complications, older individuals should maintain continuous participation in physical activity programs

\section{References}

Alfieri, F.M., Riberto, M., Gatz, L.S., Ribeiro, C.P., Lopes, J.A., \& Battistella, L.R. (2010). Functional mobility and balance in community-dwelling elderly submitted to multisensory versus strength exercises. Clinical Interventions in Aging, 9,181-5.

Armstrong, M., Bates, A., Castell, S., \& Krolik, P. (2002). Staying Active - Staying Safe: Development of a physical activity and falls prevention resource for older people who dwell in the community. NSW Public Health Bulletin, 13, 13-4.

Clemson, L., Singh, M.F., Bundy, A., Cumming, R.G., Weissel, E., Munro, J., ... Black, D. (2010). LiFE Pilot Study: A randomised trial of balance and strength training embedded in daily life activity to reduce falls in older adults. Australian Occupational Therapy Journal, 57, 42-50.

Clifford, A.M., \& Holder-Powell, H. (2010). Postural control in healthy individuals. Clinical Biomechanics, 25, 546-51.

Corriveau, H., Hebert, R., Prince, F., \& Raiche, M. (2000). Intrasession reliability of the "center of pressure minus center of mass" variable of postural control in the healthy elderly. Archives of Physical Medicine and Rehabilitation, 81, 45-8.

Da Silva, R.A., Bilodeau, M., Parreira, R.B., Texeira, D.C., \& Amorim, C.F. (2013). Age-related differences in time-limit performance and force platform-based balance measures during one-leg stance. Journal of Electromyography and kinesiology, 23, 634-39.

Domínguez-Carrillo, L.G., Arellano-Aguilar, G., \& Leos-Zierold, H. (2007). Unipedal stance time and fall risk in the elderly. Cirugia y Cirujanos, 75, 107-12.

Ekwall, A., Lindberg, A., \& Magnusson, M. (2009). Dizzy - Why not take a walk? Low level physical activity improves quality of life among elderly with dizziness. Gerontology, 55, 652-9. 
Enoka, R.M. (1994). Bases Neuromecânicas da Cinesiologia. 2 ed. São Paulo: Manole.

Franchi, K.M.B., \& Montenegro Junior, R.M. (2005). Physical activity: A necessity for good health in old age. Revista Brasileira em Promoção da Saúde, 18, 152-56.

Gil, A.W.O., Oliveira, M.R., Coelho, V.A., Carvalho, C.E., Teixeira, D.C., \& Da Silva, R.A. (2011). Relationship between force platform and two functional tests for measuring balance in the elderly. Revista Brasileira de Fisioterapia, 15, 429-35.

Gordon, C.C., Chumlea, W.C., \& Roche, A.F. (1988). Stature, recumbent length, and weight. In: T.G. Lohman, A.F. Roche and R. Martorell (Eds). Anthropometric standardization reference manual. Champaign: Human Kinetics.

Howe, T.E., Rochester, L., Jackson, A., Banks, P.M, \& Blair, V.A. (2007). Exercise for improving balance in older people. The Cochrane Database of Systematic Reviews, 17, 49-63.

Hsiao, H., \& Simeonov, P. (2001). Preventing falls from roofs: a critical review. Ergonomics, 44, 537-61.

Jiang, X., Cooper J., Porter M.M., \& Ready, A.E. (2004). Adaptation of Canada's physical activity guide and handbook for older adults: impact on functional fitness and energy expenditure. Canadian Journal of Applied Physiology, 29, 395-410.

Kuhnen, A.P., de Oliveira, A.L., Sebastini, F.F., Giumbelli, I.C., Invernizzi, L., Marques, P., ...Da Silva, T.I. (2004). Programa de atividade física para terceira idade do CDS/UFSC: O efeito do exercício físico na resistência muscular. Revista Eletrônica de Extensão, 1 .

Lafond, D., Corriveau, H., Hebert, R., \& Prince, F. (2004). Intrasession reliability of center of pressure measures of postural steadiness in healthy elderly people. Archives of Physical Medicine and Rehabilitation, 85, 896-901.

Laughton, C.A., Slavin, M., Katdare, K., Nolan, L., Bean, J.F., Kerrigan, D.C., ...Collins, J.J. (2003) Aging, muscle activity, and balance control: physiologic changes. Gait and Posture, 18, 101-8.

Lin, D., Seol, H., Nussbaum, M.A, \& Madigan, M.L. (2008). Reliability of COP-based postural sway measures and age-related differences. Gait and Posture, 28, 337-42.

Lord, S.R., Sherrington, C., \& Menz, H.B. (2001). Falls in older people: risk factors and strategies for prevention. New York: Cambridge University Press.

Marques, A.I., Rosa, M.J., Soares, P., Santos, R., Mota, J., \& Carvalho, J. (2011). Evaluation of physical activity programmers for elderly people - a descriptive study using the EFQM' criteria. BMC Public Health, 21,123.

Matsudo, S.M., Matsudo, V.K.R., \& Barros Neto, T.L.B. (2001). Atividade física e envelhecimento: aspectos epidemiológicos. Revista Brasileira de Medicina Esporte, 7, 2-13.

Mazo, G.Z., Mota, J., Benedetti, T.R.B., \& Barros, M.V.G. (2001). Validade Concorrente e Repro-dutibilidade Testereteste do Questionário de Baecke Modificado Para Idosos. Revista Brasileira de Atividade Física e Saúde, 6, 5-11.

Morley, J.E. (2007). Falls where do we stand? Missouri Medicine, 104, 63-7

Nelson, M.E., Rejeski, W.J., Blair, S.N., Ducan, P.W., Judge, J.O., King, A.C., ...Castanedaceppa, C. (2007). Physical Activity and Public Health in Older Adults: Recommendation from the American College of Sports Medicine and the American Heart Association. Medicine and Science in Sports and Exercise, 39, 1435-45.

Orr, R., Raymond, J., \& Fiatarone, S.M. (2008). Efficacy of progressive resistance training on balance performance in older adults: a systematic review of randomized controlled trials. Sports Medicine, 38, 317-43.

Orr, R. (2010). Contribution of muscle weakness to postural instability in the elderly. A systematic review. European Journal of Physical and Rehabilitation Medicine, 46, 183-220.
Parreira, R., Boer, M.C., Rabello, L.M., Costa, V., De Oliveira Júnior, E., \& Da Silva, R. A. (2013). Age-related differences in centre of pressure measures during one-leg stance is time dependent. Journal of Applied Biomechanics, 22[Epub ahead of print].

Steadman, J., Donaldson, N., \& Kalra, L. (2003). A randomized controlled trial of an enhanced balance training program to improve mobility and reduce falls in elderly patients. Journal of the American Geriatrics Society, 51, 847-52.

Viswanathan A., \& Sudarsky, L. (2012). Balance and gait problems in the elderly. Handbook of Clinical Neurology, 103, 623-34.

Viswanathan, A., \& Sudarsky, L. (2012). Balance and gait problems in the elderly. Handbook of Clinical Neurology, 103, 623-34.

Voorrips, L.E., Ravelli, A.C., Dongelmans, P.C., Deurenberg, P., \& Van Staveren, W.A. (1991). A physical activity questionnaire for the elderly. Medicine and Science in Sports and Exercise, 23, 974-79.

\section{Authors' note}

Leonardo G.V. Victor and Márcio Rogério de Oliveira are affiliated with the Center for Health Science Research, Laboratory of Functional Evaluation and Human Motor Performance (LAFUP), State University of Londrina (UEL)/University of North of Paraná (UNOPAR), and with the master's Program in Rehabilitation Sciences, State University of Londrina/University of North of Paraná, Londrina, PR, Brazil.

Denilson Castro Teixeira is affiliated with the Physical Education Department, State University of Londrina (UEL), and with the professional master's program in Physical Exercise in Health Promotion, UNOPAR, Londrina, PR, Brazil.

Maria Amélia Paes is affiliated with the with the professional master's program in Physical Exercise in Health Promotion, UNOPAR, Londrina, PR, Brazil.

Dirce Shizuko Fujisawa is affiliated with the Physical Therapy Department, State University of Londrina (UEL), University Hospital, with the Center for Health Science Research, Laboratory of Functional Evaluation and Human Motor Performance (LAFUP), University of North of Paraná (UNOPAR), and with the master's program in Rehabilitation Sciences UEL/UNOPAR, Londrina-PR, Brazil.

Nuno de Noronha da Costa Bispo is affiliated with the Physical Therapy Department, Center for Health Science Research, University of North of Paraná (UNOPAR), Londrina-PR, Brazil.

Rubens A. da Silva Junior is affiliated with the Center for Health Science Research, Laboratory of Functional Evaluation and Human Motor Performance (LAFUP), State University of Londrina (UEL)/ University of North of Paraná (UNOPAR), with the master's Program in Rehabilitation Sciences, State University of Londrina/University of North of Paraná, and with the professional master's program in Physical Exercise in Health Promotion, UNOPAR, Londrina, PR, Brazil.

\section{Corresponding author}

Denilson de Castro Teixeira, Ph.D.

Center for Health Science Research

Universidade Norte do Paraná

675 Paris Av, Londrina 86041-120, PR, Brazil

Phone: 01155 (43) 3371-7700 | Fax: 01155 (43) 3371-7721.

E-mail: denict.9@gmail.com / denilson.teixeira@unopar.br 


\section{Acknowledgements}

Rubens A. da Silva and Denilson de C. Teixeira, researchers grant recipients from the National Foundation for the Development of Private Higher Education (FUNADESP). Leonardo G.V. Vitor, supported by fellowship from CNPq. We thank Willian F. Hanes for the English revision of this paper.

Manuscript received on September 20, 2013

Manuscript accepted on July 23, 2014

\section{(c)}

Motriz. The Journal of Physical Education. UNESP. Rio Claro, SP, Brazil - eISSN: 1980-6574 - under a license Creative Commons - Version 3.0 